Legemidler i praksis

\title{
Tobakksrøyking og interaksjoner med legemidler
}

\author{
Tobakksrøyking induserer legemiddelmetaboliserende enzymer. \\ Røykere har derfor høyere dosebehov enn ikke-røykere av for eksempel \\ klozapin, olanzapin og teofyllin. Ved røykeslutt oppheves denne induk- \\ sjonen, med fare for bivirkninger dersom dosen ikke reduseres.
}

Se også kunnskapsprøve på www.tidsskriftet.no/quiz

Legemiddelinteraksjoner oppstår som oftest når to legemidler kombineres. Næringsmidler, naturmidler, rus- og nytelsesmidler kan imidlertid også påvirke effekten av legemidler. Et aktuelt eksempel er tobakksrøyking, som kan påvirke både farmakodynamikk og farmakokinetikk av legemidler (1-3). Den farmakodynamiske effekten er primært knyttet til blodtrykksstigning, den farmakokinetiske effekten skyldes økt metabolisme som følge av enzyminduksjon av cytokrom P450 1A2 (CYP1A2) og uridindifosfat-glukuronosyltransferaser (UGT). I forhold til legemiddelinteraksjoner regnes den farmakokinetiske effekten av tobakksrøyking som viktigere enn den farmakodynamiske.

Selv om andelen tobakksrøykere gradvis er blitt redusert de siste 30 årene, er det fortsatt om lag en firedel av den norske befolkningen som røyker daglig. I enkelte pasientgrupper er andelen vesentlig større, og ved tilstander som kronisk obstruktiv lungesykdom og schizofreni er andelen røykere spesielt høy. Teofyllin, klozapin og olanzapin er viktige eksempler på legemidler som brukes i disse pasientgruppene og som påvirkes av tobakksrøyking. Interaksjoner med disse og flere andre legemidler (tab 1) kan få betydelige kliniske konsekvenser. Her belyses aspekter ved interaksjoner mellom legemidler og tobakksrøyk som klinikere bør være klar over.

\section{Materiale og metode}

Artikkelen bygger på forfatternes egen erfaring innen feltet, supplert med ikke-systematiske litteratursøk i PubMed.

\section{Hva induserer metabolismen?}

Tobakksrøyk inneholder nærmere 5000 ulike stoffer. I røyken foreligger $10 \%$ av stoffene i gassfase, resten foreligger som partikler. Gassfasen inneholder blant annet karbonmonoksid, karbondioksid, ammoniakk og benzen. I partiklene finnes blant annet tjære, nikotin og polysykliske aromatiske hydrokarboner (PAH). Sistnevnte dannes ved ufullstendig forbrenning av organisk materiale og er ansvarlig for tobakksrøykens induksjon av metaboliserende enzymer (fig 1).
Induksjonen skjer ved at polysykliske aromatiske hydrokarboner aktiverer kjernereseptorer som regulerer avlesning (transkripsjon) av gener som koder for CYP1A1, CYP1A2 og UGT-enzymer. CYP1A1 aktiverer prokarsinogene stoffer, og den økte risikoen for lungekreft hos røykere er assosiert med tobakksrøykingens induksjon av dette enzymet (1). CYP1A2 er viktig i legemiddelmetabolisme, og tobakksrøykingens induksjon av dette enzymet er hovedårsaken til legemiddelinteraksjoner (1). UGT-enzymfamilien kobler glukuronsyre på endogene og eksogene stoffer. Den består av mange ulike enzymer, og en rekke av dem er involvert i omsetning av legemidler (4). Polysykliske aromatiske hydrokarboner har trolig ulik induserende effekt på forskjellige UGT-enzymer, og det er derfor variabelt i hvilken grad tobakksrøyking påvirker legemidler som glukuronideres (1).

\section{Induksjon og antall sigaretter}

I noen få studier har man undersøkt om antall røykte sigaretter er av betydning for enzyminduksjonen. I en studie med CYP1A2-substratet koffein var det økende induksjonsgrad fra én til ti sigaretter per dag, men ingen vesentlig økning ved større forbruk enn dette (5). Tilsvarende ble det $\mathrm{i}$ en annen studie med CYP1A2-substratene klozapin og olanzapin ikke observert forskjeller i plasmakonsentrasjonen hos schizofrene som røykte henholdsvis $7-12$ og mer enn 12 sigaretter per dag (6). I denne studien var det ikke noen som røykte under sju sigaretter per dag. Hos ikke-røykerne var plasmakonsentrasjonen i gjennomsnitt dobbelt så høy som hos røykerne.

De aller fleste røykere røyker rundt ti sigaretter eller mer per dag. Det betyr i praksis at det primært er røyking/ikke-røyking og i mindre grad antall sigaretter som er relevant i forhold til legemiddelinteraksjoner. Interaksjonsgraden av røyking varierer imidlertid mye mellom ulike individer, helt uavhengig av antall sigaretter per dag. Dette kan skyldes genetiske forhold, men foreløpig er det begrenset kunnskap om dette. Genanalyse av CYP1A2 er derfor ikke tilgjengelig som et praktisk verktøy for å forutsi interaksjonsgrad mellom legemidler og tobakksrøyk.

\section{Varighet etter røykeslutt}

Ved røykeslutt vil induksjonen reverseres og enzymaktiviteten gradvis reduseres tilbake til pasientens habitualnivå. I en studie fant man en halveringstid på omtrent to dager for reversering av induksjonseffekten (7). Det betyr at induksjonseffekten er omtrent halvert allerede etter to dager og redusert til $25 \%$ etter fire. Etter omtrent ti dager vil induksjonseffekten være helt reversert.

Fordi det ikke er nikotinet i tobakksrøyken som er ansvarlig for induksjonen av metaboliserende enzymer, vil induksjonseffekten også opphøre ved overgang til andre nikotinholdige produkter, som snus eller legemidler.

\section{Kliniske konsekvenser}

Den induserende effekten av tobakksrøyking fører til lavere plasmakonsentrasjoner ved en gitt dosering av en rekke legemidler som metaboliseres av CYP1A2 og/eller UGT (tab 1). For de fleste røykere innebærer dette økt dosebehov for å oppnå tilfredsstillende terapeutisk effekt. Så lenge dosen er oppjustert for å kompensere for induksjonen, har imidlertid interaksjonen ingen praktisk betydning.

Et interessant fenomen er at mer enn $80 \%$ av pasientene med schizofreni røyker (6). Det betyr at standard anbefalt dosering av klozapin og olanzapin primært er tilpasset røykernes behov. Dermed kan ikke-røykerne være utsatt for en høyere bivirkningsrisiko ved bruk av vanlige standarddoser. Hos ikke-røykere er det derfor ekstra viktig å være oppmerksom på bivirkninger og moni-

\section{Hovedbudskap}

- Tobakksrøyk inneholder stoffer som induserer metabolismen av en rekke legemidler via enzymene CYP1A2 og UGT

- Ved røykeslutt/midlertidig opphold er det fare for overdosering og bivirkninger av aktuelle legemidler hvis dosen ikke reduseres

- Siden enzyminduksjonen ikke skyldes nikotin, er faren for overdosering og bivirkninger den samme ved overgang til andre nikotinholdige produkter 
